\title{
Iron oxide and calcite associated with Leptothrix sp. biofilms within an estavelle in the upper Floridan aquifer
}

\author{
Lee J. Florea ${ }^{1}$, Chasity L. Noe-Stinson ${ }^{2}$, Josh Brewer ${ }^{2}$, Rick Fowler ${ }^{3}$, Joe B. Kearns ${ }^{4}$ \\ and Anthony M. Greco ${ }^{5}$
}

\begin{abstract}
:
Abstract

Florea L.J., Noe-Stinson C.L., Brewer J., Fowler R., Kearns B.J. and Greco A.M. 2011. Iron oxide and calcite associated with Leptothrix sp. biofilms within an estavelle in the upper Floridan aquifer. International Journal of Speleology, 40 (2), 205-219. Tampa, FL (USA). ISSN 0392-6672. DOI 10.5038/1827-806X.40.2.12

In Thornton's Cave, an estavelle in west-central Florida, SEM, EDS, and XRD data reveal biofilms that are predominantly comprised of $\mathrm{FeOOH}$-encrusted hollow sheaths that are overgrown and intercalated with calcite. Fragments of this crystalline biofilm adhere to the walls and ceiling as water levels vary within the cave. Those on the wall have a 'cornflake' appearance and those affixed to the ceiling hang as fibrous membranes. PCR of DNA in the active biofilm, combined with morphologic data from the tubes in SEM micrographs, point to Leptothrix sp., a common Fe-oxidizing bacteria, as the primary organism in the biofilm. Recent discoveries of 'rusticles' in other Florida caves suggest that Fe-oxidizing bacteria may reside elsewhere in Florida groundwater and may play a role in the mobility of trace metals in the Upper Florida aquifer. SEM micrographs from two marble tablets submerged for five months, one exposed to microbial activity and a second isolated from microbial action, revealed no visible etchings or borings and very limited loss of mass. EDS data from the electron micrographs of the unfiltered tablet document the same FeOOH-encrusted hollow sheaths and similar deposits of calcite as seen in the 'cornflakes'. These results, combined with water chemistry data imply that the biofilm may focus or even promote calcite precipitation during low-water level conditions when $\mathrm{CO}_{2}$ degasses from the cave pools.
\end{abstract}

Keywords: scanning electron microscopy; x-ray diffraction, electron diffraction spectroscopy, polymerase chain reaction; Thornton's Cave, Florida; geomicrobiology

Received 14 December 2010; Revised; 25 May 2011; Accepted 15 June 2011

\section{INTRODUCTION IRON AND MANGANESE OXIDIZING BACTERIA}

Iron-oxidizing $(\mathrm{Fe})$ and manganese-oxidizing $(\mathrm{Mn})$ bacteria are ubiquitous to the near-surface realm. In particular, examples of bacteria that utilize iron in their life cycle are documented by Spring (2006) and Ghiorse (1984) and include freshwater ponds, lakes,

${ }^{1}$ Department of Geological Sciences, Ball State University, 2000 W. University Ave. Muncie, IN 47306

${ }^{2}$ Department of Geography and Geology, Western Kentucky University, 1906 College Heights Blvd, Bowling Green, KY 42101

${ }^{3}$ Center for Water Resource Studies, Western Kentucky University, 1906 College Heights Blvd, Bowling Green, KY 42101

${ }^{4}$ Materials Research Institute, The Pennsylvania State University, A1 Materials Research Laboratory Building, University Park, PA 16802

${ }^{5}$ College of Marine Science, University of South Florida, Knight Oceanographic Center, 140 7th Avenue South, St. Petersburg, FL 33701 and wetlands (Emerson \& Revsbech, 1994), acid mine drainage and chalybeate springs (Casanova et al., 1999), hydrothermal vents (Emerson \& Moyer, 2002), bio-fouled wells and water distribution systems (Li et al., 2010), and potentially desert varnish (Perry et al., 2003). These bacteria bind $\mathrm{Fe}(\mathrm{III})$ - and $\mathrm{Mn}(\mathrm{IV})$-oxides, such as ferric oxyhydroxide ( $\mathrm{FeOOH})$, through active enzymatic or passive sorption of dissolved $\mathrm{Fe}(\mathrm{II})$ and $\mathrm{Mn}(\mathrm{II})$ to negatively charged cell walls or sheaths (Frankel \& Bazylinski, 2003; Northup \& Lavoie, 2001; Konhauser, 1997, 1998; Lowenstam \& Weiner, 1989) through the representative oxidation reaction,

$$
2 \mathrm{Fe}^{3+}+3 / 2 \mathrm{O}_{2}+\mathrm{H}_{2} \mathrm{O} \rightarrow \downarrow 2 \mathrm{FeOOH} .
$$

In the natural environment, there is a wide range of bacteria with $\mathrm{Fe}$ - and $\mathrm{Mn}$-oxidizing characteristics, such as Leptothrix sp., Sphaerotilus sp., Clonothrix sp., Thiothrix sp., Galionella ferruginea, among others. Leptothrix ochracea, in particular, was among the first microorganisms to be described by scientists in the late 1700 s and was likely named after the orange 
ocherous deposits of Fe-oxides visible within bodies of slowly moving freshwater (Spring, 2006).

In karst aquifers and cave ecosystems, $\mathrm{Fe}$ - and Mn-oxidizing bacteria have received sporadic, but increasing, attention. For example, Peck (1986), using cultures from mud and from wall crusts in Level Crevice Cave in Iowa, demonstrated the presence of Leptothrix sp. and Galionella ferruginea within these sediments. In a similar study, Moore (1981) identified Leptothrix sp. in waters from Matts Black Cave in West Virginia and proposed a link between these bacteria and the occurrence of birnessite (a $\mathrm{Mn}(\mathrm{IV})$-oxide) coating stream cobbles. In Lechuguilla Cave, New Mexico, Davis et al. (1990) identified 'rusticles' of iron oxides and organic filaments using scanning electron microscopy (SEM), which have been interpreted by Provencio \& Polyak (2001) as fossilized Clonothrix sp. or similar Fe-oxidizing bacteria. Northup et al. (2003) survey this and other microbial communities inhabiting ferromagnesite deposits of Lechuguilla Cave.

Recent publications further demonstrate the range of $\mathrm{Fe}$-oxidizing bacteria in the karst environment. For example, Zhou et al. (2007) identify Leptothrix sp. within the walls of an 'earth-cave' (a cave formed entirely within soil) in the Guizhou province of China. In the Borra Caves near Vishakapatnam, India, Baskar et al. (2008) identified Leptothrix-like and Galionellalike bacterial within microbial mats from in-cave springs and seeps that have near-neutral $\mathrm{pH}$. More recently, Frierdich \& Catalano (2009) have identified Leptothrix-like and Galionella-like bacteria in $\mathrm{FeOOH}$ deposits coating speleothems within Pautler Cave in southwest Illinois.

We present herein an example from a cave in west-central Florida, Thornton's Cave, where we document $\mathrm{Fe}$-oxidizing bacteria that manifest on the water surface as thin surface films, on the cave walls as 'cornflakes', and on the ceiling as fibrous membranes. Recent interest and concerns with the mobility of trace metals in Florida surface water and groundwater provides relevance to this study. For example, Katsoyiannis \& Zouboulis (2004) demonstrate the effectiveness of $\mathrm{Fe}$-oxidizing bacteria at removing As(III) and As(V) along with dissolved Fe(II) from water. Frierdich \& Catalano (2009) confirm the incorporation of $A s(V)$ and other heavy metals within surface complexes of cave-based Fe-oxides in Illinois. This may be a useful water-treatment consideration in south Florida, where increased levels of As(III) and $\operatorname{As}(\mathrm{V})$ have been documented in groundwater recovered from the Upper Floridan aquifer (UFA) following the introduction of oxygenated waters into aquifer storage and recovery systems (e.g. Arthur et al., 2002; Price, 2003).

\section{GEOLOGY AND HYDROLOGY OF THORNTON'S CAVE}

Thornton's Cave comprises a maze of $250 \mathrm{~m}$ of shallow, orange-stained, fracture-oriented passages formed within the upper third of the Eocene-age Ocala Limestone of the UFA (Fig. 1), an unconfined to semi-confined karst aquifer within westcentral Florida. Matrix permeabilities of the Ocala
Limestone range over three orders of magnitude, from $10^{-11.5}$ to $10^{-14.5} \mathrm{~m}^{2}$, and characterize this karst aquifer as eogenetic-in other words, the rock matrix retains considerable depositional porosity and permeability (Vacher \& Mylroie, 2002). Budd \& Vacher (2004) illustrate the hydraulic properties of the Ocala Limestone and the importance of matrix flow in the confined portions of the UFA. Florea \& Vacher $(2006,2007)$ document the characteristics of karst hydrology in the eogenetic limestones of the unconfined UFA in west-central Florida.

Thornton's Cave is located to the east of the Brooksville Ridge in the southern portion of the Tsala Apoka Plain-a geomorphic province of White (1970) characterized by lakes, swamps, and other wetlands separated by limestone uplands of low relief. The Withlacooche River flows through this province and less than one kilometer to the west of the cave (Fig. 1). Air-filled caves such as Thornton's are common within the Brooksville Ridge and along Withlacoochee River. The architecture of these caves is described within Florea (2006).

River stage has a significant impact upon the hydrology of the Thornton's cave. Specifically, the cave behaves as an estavelle - a karst feature that acts either as a spring or a sink for water. In low water levels, isolated pools occupy portions of the cave near the Tangerine Entrance and 'The Deep'. At times when water levels in the cave are higher, the first author and fellow cavers have observed water rising from a narrow pool at the Tangerine entrance (Fig. 1), flowing through the cave, and discharging into a cypress swamp and open wetland adjacent to the Withlacoochee River. During periods of high river stage, such as that observed by McGee (2010) during the El Niño-Southern Oscillation (ENSO) event from July through September of 2009, water from the river recharges the cave and the UFA. Such behavior is common in Florida within cave systems that adjoin major rivers. Martin \& Dean (2001), for example, provide compelling geochemical evidence from the Santa Fe Sinks and Rise in north-central Florida that illustrate that high and low stages in the Santa Fe River recharge and discharge the UFA in the vicinity of the underlying cave system, respectively (Martin et al., 2006; Moore et al., 2009).

In the literature, Thornton's Cave has alternatively been referenced as a bat cave and a diving site. In the case of the former, seasonal maternity roosts of the Southeastern Bat, Myotis austroriparius, reside in several passages. These roosts produce deposits of guano that certainly interact with the cave waters. In the latter case, a diving site, the 1975 Underwater Society of America International Divers' Guide states that the

[m]ain spring has been recorded to [32 m] depth; however, it silts up very easily, and has several restrictions before reaching the [32 $\mathrm{m}$ ] level...Don't go down narrow shaft to [the $32 \mathrm{~m}$ ] level as there are loose boulders, decreasing visibility, and a maze of tunnels (Underwater Society of America, 1975, p. 55). 


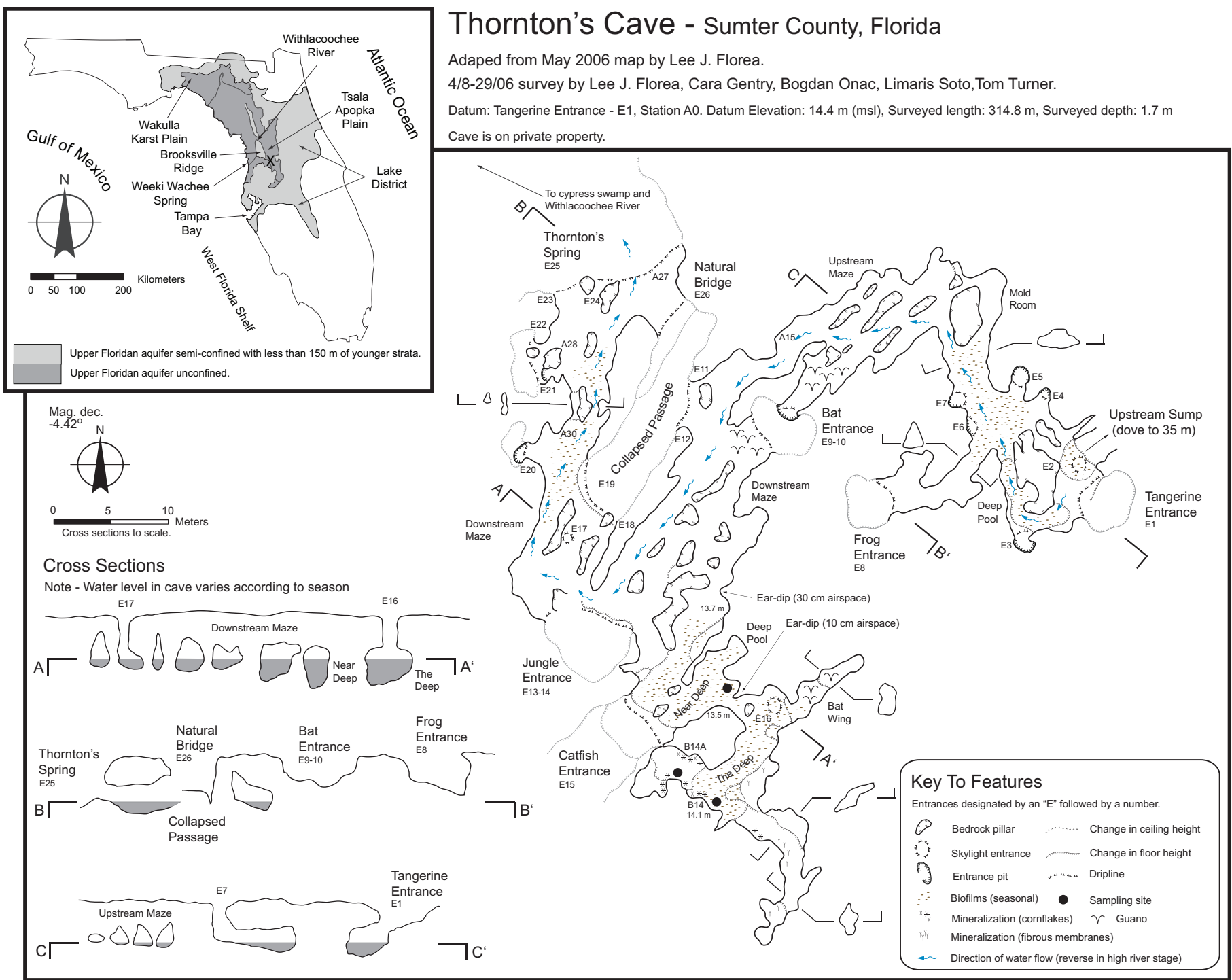

Fig. 1. Map of Thornton's Cave including representative passage and linear cross-sections. Distribution of biofilms represent conditions in low water levels. Sampling sites for this study are shown as black circles. (Inset) Location of Thornton's Cave (shown by an ' $X$ ') and associated geomorphic features, including regions where the Upper Floridan aquifer is unconfined and semi-confined.

In fact, cave diver Brett Hemphill documented two sites of deeper passage during the fall of 2007-the pool at the Tangerine Entrance and in 'The Deep' (Fig. 1). At the Tangerine Entrance, he recorded a depth of approximately $35 \mathrm{~m}$ and produced a sketch illustrating several drops and constrictions. In 'The Deep' he noted deeper passages but did not descend through a school of large catfish (Tom Turner, pers. comm., 2007).

Most explored passages in Thornton's Cave, however, are located within the vertical range of the annual water table and average $14 \mathrm{~m}$ above present sea level (Fig. 1). Florea et al. (2007) address the tiered nature of caves in west-central Florida in particular and note that levels of passages are common at approximately $12-15 \mathrm{~m}$ above modern sea level and $35 \mathrm{~m}$ below the modern water table. This publication also hypothesized that sediments from the Withlacoochee River infiltrate karst features and reduce the permeability of the UFA below the Tsala Apoka Plain. One result is potentiometric surfaces that are more than 10-m-higher than a few kilometers to the west in the Brooksville Ridge. The data from Thornton's Cave is consistent with these observations and supports the interpretation of Florea et al. (2007) that many caves in Florida mark positions of the paleo-water table and are multi-generational.

\section{GEOCHEMICAL PROFILE OF THORNTON'S CAVE}

Perhaps one of the most visible characteristics of Thornton's Cave is the number and density of entrances (26 at present; Fig. 1). These entrances and the occasional input of river water bring organic matter into the cave. In fact, Thornton's Cave is biologically active with a wide range of observed vertebrate, invertebrate, fungal, and bacterial communities.

McGee (2010) recently completed a 16-month geochemical survey of the cave and surface water, the cave air, and cave walls with the objective of characterizing the flux of carbon in this setting. The data, briefly summarized, demonstrate a ready exchange of atmosphere between the cave and the surface; with average $\mathrm{CO}_{2}$ levels lower near the Tangerine Entrance, greater near the Catfish Entrance (Fig. 1), with greatest concentrations in the 'Bat Wing' 
near 'The Deep' (Table 1). The calculated $\mathrm{pCO}_{2}$ within the cave pools, in contrast, are on average lowest in the 'Bat Wing, greater at the Catfish Entrance, and greatest at the Tangerine Entrance (Table 1). Some depleted values of $\delta^{13} \mathrm{C}_{\text {DIC }}$ in the cave air, particularly in the 'Bat Wing', suggest that a portion of the $\mathrm{CO}_{2}$ is likely derived from the aerobic respiration of bats and microbial-decomposition of associated guano (Table 1). Production of $\mathrm{CO}_{2}$ within cave substrates by microbial activity was confirmed in $\mathrm{CO}_{2}$ productionrate experiments using a variety of cave substrates (Table 1). She concludes that active dissolution of the limestone bedrock is occurring in the cave, primarily driven by the forward reaction in the carbon dioxidecarbonate system, or in representative form,

$$
\mathrm{H}_{2} \mathrm{O}+\mathrm{CO}_{2}+\mathrm{CaCO}_{3} \rightarrow \mathrm{Ca}^{2+}+2 \mathrm{HCO}_{3}^{-} .
$$

She supports this with evidence from the limestone tablets, which lost between $2.5 \%$ and $3.5 \%$ of their total mass during the period of study (Table 1).

The field and ion chemistry documented in McGee (2010), supplemented by two samples collected in March of 2009 by the first and third authors, reveal cave waters that are seasonally rich in dissolved solids. For example, measurements of total alkalinity and hardness in low water-level conditions between December of 2008 and July of 2009 averaged $233 \mathrm{mg} / \mathrm{L}$ and $241 \mathrm{mg} / \mathrm{L}$, respectively. Specific conductance (SpC) during this same period ranged between $450 \mu \mathrm{S}$ and $510 \mu \mathrm{S}$. Measurements of total Fe between March of 2009 and November of 2009 ranged between 1.4 $4.2 \mathrm{mg} / \mathrm{L}$ with lower concentrations occurring during the rainy season and $10 \%$ or less of the total Fe in the soluble Fe(II) form. In contrast, the few measurements of $\mathrm{SO}_{4}{ }^{2-}$ and $\mathrm{Cl}^{-}$in the spring of 2009 exceeded $18 \mathrm{mg} / \mathrm{L}$ and $10 \mathrm{mg} / \mathrm{L}$, respectively, until the onset of the rainy season in May when they decreased and ultimately dropped below the detection limit once water from the Withlacoochee River, with lower alkalinity, hardness, and $\mathrm{SpC}$, flooded the cave.

\section{IRON STAINS, SURFACE FILMS, AND MINERALIZATIONS IN THORNTON'S CAVE}

Another distinctive characteristic of Thornton's Cave are the ever-present orange stains of iron oxides (Fig. 2A) along with frequent brown to black ceiling stains and encrustations. Furthermore, iron oxides noticeably flocculate within the water, congealed within globs of 'slime' noted by the cave mapping team during 2006 and during dive exploration in 2007. Additionally, iron-oxides are incorporated into the cave sediments as an orange ochre that easily, and permanently, stains clothes.

During the lower than average water-level conditions that persisted from 2006 into the summer of 2009, the pools of water throughout the cave developed an orange surface film that was somewhat elastic and which broke into polygonal rafts (Figs. $2 \mathrm{~B}$ and $\mathrm{C}$ ), therefore combining the characteristic of films of biological (elastic) and mineralogical (brittle) composition. In the portions of the cave that are isolated from an entrance, such as 'The Deep' (Fig. 1 ), orange-colored fibrous membranes that are paper thin hang from the ceiling and orange-colored and cereal-like 'cornflakes' concentrate at the elevation of the mean water table.

What motivates this investigation are the structure and composition of these surface films, 'cornflakes', and fibrous membranes and what this information potentially implies about the process by which they were formed. As documented in this introduction, these particular deposits may be present in caves whenever the geochemistry of water has the appropriate composition. For example, recent underwater cave exploration at Weeki Wachee

Table 1 - A) Average $\mathrm{CO}_{2}$ concentrations and $\delta^{13} \mathrm{C}_{\mathrm{CO} 2}$ in cave air, $\mathrm{pCO}_{2}$ concentration and $\delta^{13} \mathrm{C}_{\mathrm{co} 2}$ in cave pools in Thornton's Cave; B) $\mathrm{CO}_{2}$ production rates and $\delta^{13} \mathrm{C}_{\mathrm{CO} 2}$ values from cave substrates; C) Limestone tablet mass before and after deployment (data synthesized from Tables 4.1-4.4 of McGee (2010)).

\begin{tabular}{|c|c|c|c|c|}
\hline \multirow[t]{2}{*}{ A) Site } & \multicolumn{2}{|c|}{ Cave Air } & \multicolumn{2}{|c|}{ Cave Pool } \\
\hline & $\mathrm{CO}_{2}(\mathrm{ppm})$ & $\delta^{13} C_{\text {co2 }}(\%)$ & $\mathrm{pCO}_{2}(\mathrm{~atm})$ & $\delta^{13} C_{\mathrm{co} 2}(\% 0)$ \\
\hline Tangerine Entrance & 452 & -10.9 & 0.00360 & -5.1 \\
\hline Catfish Entrance & 573 & -12.9 & 0.00214 & -5.3 \\
\hline Bat Wing & 982 & -16.6 & 0.00145 & -4.8 \\
\hline B) Substrate & \multicolumn{2}{|c|}{$\begin{array}{c}\mathrm{CO}_{2} \text { Production Rate } \\
\left(\mu \mathrm{mol} \mathrm{m} \mathrm{m}^{-3} \mathrm{~s}^{-1}\right)\end{array}$} & \multicolumn{2}{|c|}{$\delta^{13} C_{\mathrm{co} 2}(\%)$} \\
\hline Wet cave rock & \multicolumn{2}{|c|}{0.23} & \multicolumn{2}{|c|}{-18.5} \\
\hline Dry cave rock & \multicolumn{2}{|c|}{0.18} & \multicolumn{2}{|c|}{-13.2} \\
\hline Wet cave sediment & \multicolumn{2}{|c|}{0.15} & \multicolumn{2}{|c|}{-21.2} \\
\hline Dry cave sediment & \multicolumn{2}{|c|}{0.10} & \multicolumn{2}{|c|}{-20.3} \\
\hline Surface soils & \multicolumn{2}{|c|}{0.33} & \multicolumn{2}{|c|}{-23.1} \\
\hline C) Site & Initial mass (g) & Final mass (g) & Difference (g) & $\%$ Lost \\
\hline Tangerine Entrance & 26.908 & 25.967 & 0.941 & 3.497 \\
\hline Surface soils & 31.076 & 30.298 & 0.778 & 2.504 \\
\hline
\end{tabular}



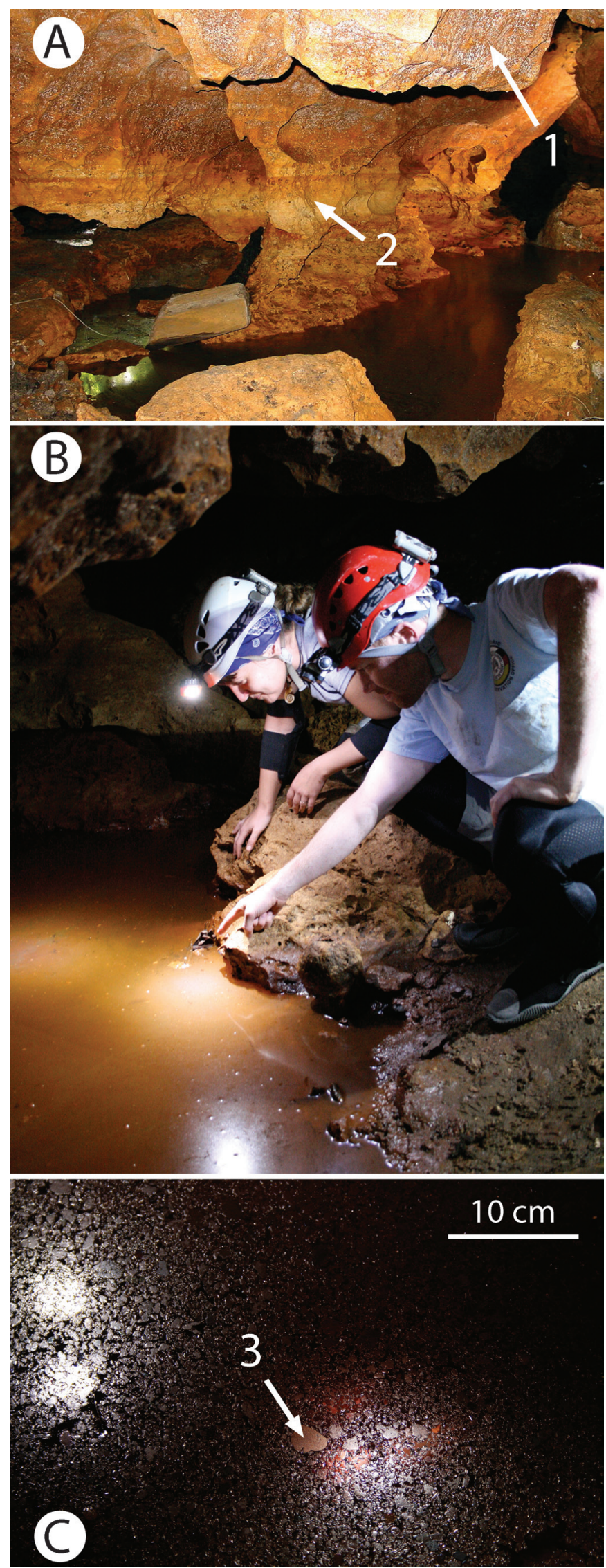

Springs in Hernando County, Florida suggests that our experience in Thornton's Cave is not unique. Of particular relevance is the discovery in 2007 of massive deposits of 'rusticle' formations at water depths below $70 \mathrm{~m}$ (Karst Underwater Research, 2009), which litter the floor of the cave and hang from large pieces of breakdown (Fig. 3A). The morphology of these formations is similar to those found on the hull of the RMS Titanic in 1996 (Cullimore et al., 2002). Surface analysis using energy-dispersive X-ray spectroscopy (EDS) confirm that iron dominates the elemental composition (Fig. 3B; Cindy Fischler, pers. comm., 2010).

\section{METHODS}

At the core of this investigation are samples from Thornton's Cave of 'cornflakes' from the cave walls and fibrous membranes on the ceiling collected in 'The Deep' during the fall of 2007 (Fig. 1), experiments in a cave pool during 2007-2008 on polished marble tablets in microbial diffusion chambers, and genetic tests on active biofilms collected from a cave pool in the spring of 2009. The purpose behind these samples was to establish the link between the surface films, the 'cornflakes', and fibrous membranes and provide an explanation for their genesis.

In February of 2008, we prepared samples of the 'cornflakes' with a sputter coat of Au-Pd and collected micrographs at high vacuum (SE and BSE modes) and at a range of magnifications on a Hitachi S-3500 N SEM at the University of South Florida College of Marine Science (USF-CMS). Micrographs were collected at an accelerating voltage of $15 \mathrm{keV}$ with working distances that ranged between 8 and $11 \mathrm{~mm}$. Elsewhere, a Princeton Gamma Tech microanalysis system attached to a Hitachi S-3500 N SEM at the Materials Research Institute at the Pennsylvania State University (PSU-MRI), collected EDS and thus elemental data on an uncoated sample of the 'cornflakes' in variable-pressure mode at an accelerating voltage of $20 \mathrm{keV}$, a variable-width filter, and a takeoff angle of 28.9 degrees.

During the same time period, X-ray diffraction (XRD) data were collected on powdered samples of the 'cornflakes' and fibrous membranes using a Scintag X2 theta-theta powder diffractometer at PSU-MRI that allowed the sample to be mounted in a horizontal position. Data were collected using a $\mathrm{Si}(\mathrm{Li})$ peltier from $3^{\circ}-80^{\circ} 2 \theta$ using a step size of $0.2^{\circ} 2 \theta$ and a count time of 2 seconds. Mineral identification was performed by comparing the acquired diffraction data with reference patterns provided by the International Centre for Diffraction Data.

As part of this investigation, two tablets of micropolished Italian marble were deployed in Thornton's Cave for five months during the winter of 2007-2008 near the Catfish Entrance (Fig. 1) in a manner similar

Fig. 2. A) Passage in Thornton's Cave near the Tangerine Entrance (photo by Tom Turner). Passage height is approximately 1.5 meters: 1. Organic material (bacterial and/or fungal) growing upon ceiling. 2. Watermark at the elevation of the mean water table. Note the orange staining of the ordinarily white Eocene-age Ocala Limestone. B) Lee Florea and Chasity Noe-Stinson investigate films on the water surface at the site of collection in one of the many pools of Thornton's Cave in 2009 during the dry season and low water levels (photo by Amber Yuellig). Note the orange color of the surface films. C) Close up image that demonstrates the polygonal nature of the surface films at the same location as the above photo. 3. One of the polygonal fragments that is of the same scale as the 'cornflakes' that accumulate on the walls of the cave in the remote southern part of the cave, 'The Deep' primarily at the elevation of the mean water table. 

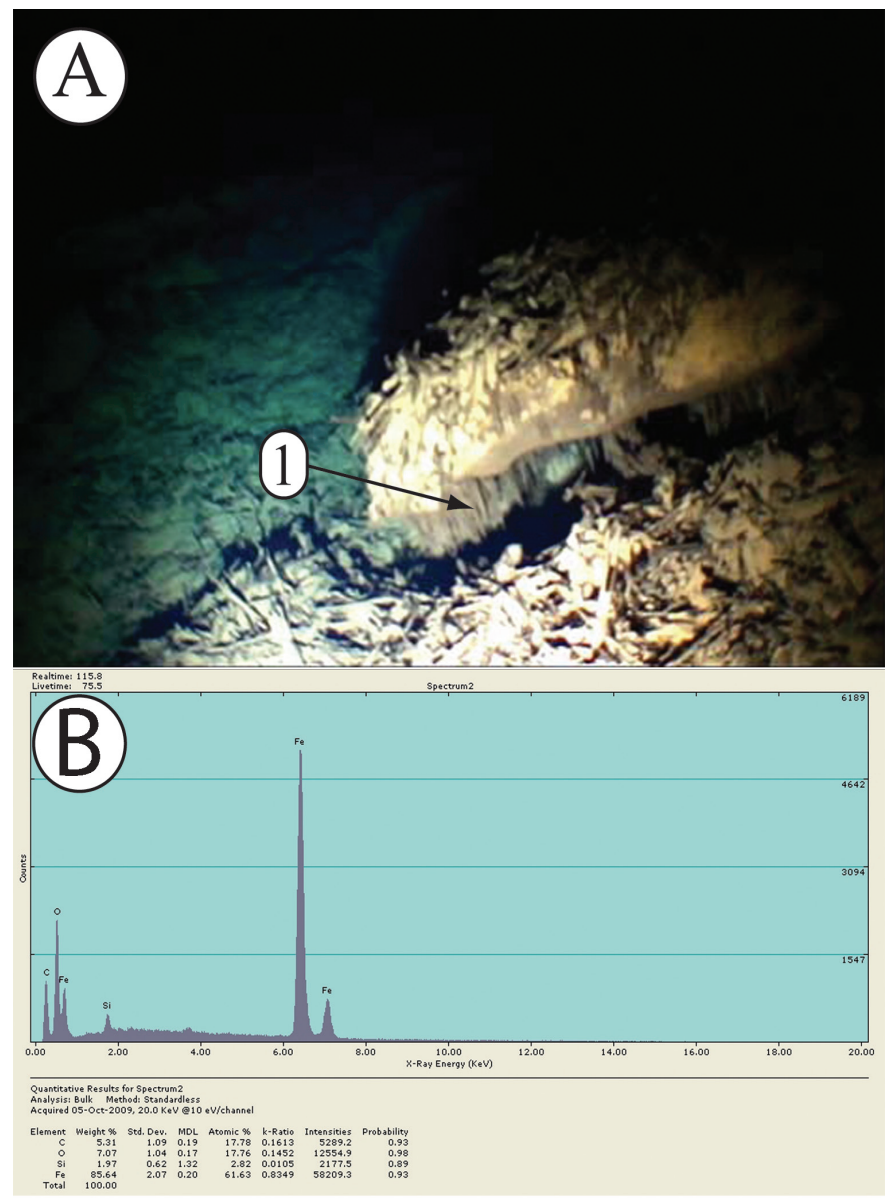

Fig. 3. Underwater photo, SEM micrograph, and EDS data from 'rusticle' formations in Weeki Wachee Springs. A) Photo of 'rusticle' formations at a depth of approximately $70 \mathrm{~m}$ (reprinted, with permission, from Fig. 12 of Karst Underwater Research, 2009). Broken 'rusticles' litter the floor of the passage in this still image from an underwater video. Arrow at ' 1 ' points to intact 'rusticles' that hang from a block of breakdown (camera is held at an angle-the rusticles under the rock are vertical). Length of largest 'rusticles' is approximately $35 \mathrm{~cm}$. B) EDS spectra collected from the center of the above electron micrograph with associated elemental analysis (data provided courtesy of Cindy Fischler at the FGS). The data quantify the relative proportion of iron and oxygen in this portion of the 'rusticle'.

manner to that conducted in a previous collaborative study in the Everglades documented in Chapter 5 of McGee (2010). While the marble is not local, such as the Ocala Limestone tablets deployed in Thornton's by McGee (2010), the mineralogy is well constrained. XRD data in 2007 by Core Laboratories in Broussard, Louisiana document these tablets to consist of nearly $100 \%$ calcite with trace quantities of quartz.

Prior to this study, during the summer of 2007 , the tablets were sterilized by heating to $900{ }^{\circ} \mathrm{C}$ for four hours to remove organic matter and weighed for initial mass. The tablets were next washed in isopropyl alcohol, wrapped in aluminum foil, and autoclaved for 20 minutes to ensure sterilization. Pre-deployment SEM micrographs collected on the unaltered and uncoated tablets at the USF-CMS documented the overall surface appearance and texture of the tablets. Electron micrographs were collected at a low-pressure setting of $25 \mathrm{~Pa}$ with an accelerating voltage of $15 \mathrm{keV}$, and with working distances that ranged between 14.7 $\mathrm{mm}$ and $15.3 \mathrm{~mm}$.

In the cave, both tablets were deployed at a water depth that measured $30 \mathrm{~cm}$ at the time of deployment and changed during the course of this study as documented in McGee (2010). During the five-month period of study, tablets were enclosed within milled acrylic chambers with set screws using a design by John Lisle of the U.S. Geological Survey; one tablet was exposed directly to the cave water and the second encased behind a $0.2 \mu \mathrm{m}$ diffusion membrane using o-rings for the seal and Teflon tape for the set screws. Following the deployment, the samples were lightly rinsed, weighed, and any organic matter fixed to the tablet surface using a process described by Fratesi et al. (2004) that involved a two-hour bath in $2.5 \%$ glutaraldehyde in a $0.1 \mathrm{M}$ potassium phosphate buffer, followed by ten minutes each in 35\%, 50\%, $70 \%$, and $95 \%$ ethanol, six ten-minute changes of $100 \%$ ethanol, and ten-minute baths in 50\% and 100\% hexamethyldisilazane (HMDS).

Post-deployment SEM micrographs were collected on the tablets at USF-CMS during July of 2008 after receiving a sputter-coat of Au-Pd. Micrographs were collected at high-vacuum using an accelerating voltage of $15 \mathrm{keV}$ and working distances that ranged between 11 and $16 \mathrm{~mm}$. Electron micrographs in this post-deployment set correspond in location and magnification to the set of pre-deployment electron micrographs. The final electron micrograph database consists of before and after pictures that document changes to the tablet surface. While collecting this post-deployment SEM imagery, we used an EDAX microanalysis system for x-rays at an accelerating voltage of $15 \mathrm{keV}$ and a Robison backscatter detector for atomic number contrast.

Next, a sample of the film from the water surface in the cave was collected in the spring of 2009 (Fig. 2B). DNA isolated from the orange surface film was separated using a centrifuge and amplified using polymerasease chain reaction (PCR) over 40 cycles with a primer pair described within Gheriany et al. (2009) that reacts specifically with the mofA gene and encodes the $\mathrm{Mn}(\mathrm{II})$-oxidation enzyme characteristics of Leptothrix sp. bacteria. During PCR, we used a melting point analysis to check for a change in sample fluorescence over a range in temperatures to demonstrate that the amplified product was a discrete DNA fragment. To check our analysis for any effects of changing volume, we preformed tests for both the DNA from the surface film and the Bacteroides $16 \mathrm{~S}$ rDNA at three sample volumes, $1 \mu \mathrm{L}, 5 \mu \mathrm{L}$, and $10 \mu \mathrm{L}$.

To determine the relative size of the DNA fragment amplified by PCR, we ran a $1.5 \%$ agarose gel in a TAE buffer ( $\mathrm{pH} 7.8$ ) in a $7 \mathrm{~V} / \mathrm{cm}$ electric field using a BioRad minigel platform $(10 \mathrm{~cm})$. The electrophoresis sorts the molecules of DNA into bands based on size to charge ratio. The distance a band travels is inversely proportional to the logarithm of the length in base pairs of the DNA fragment. In our results, we compare the fragment sizes to known standards and negative controls. For a standard we used a New England Biolabs $1 \mathrm{~kb}$ ladder, and for the negative controls we utilized both water and Bacteroides $16 S$ rDNA. 


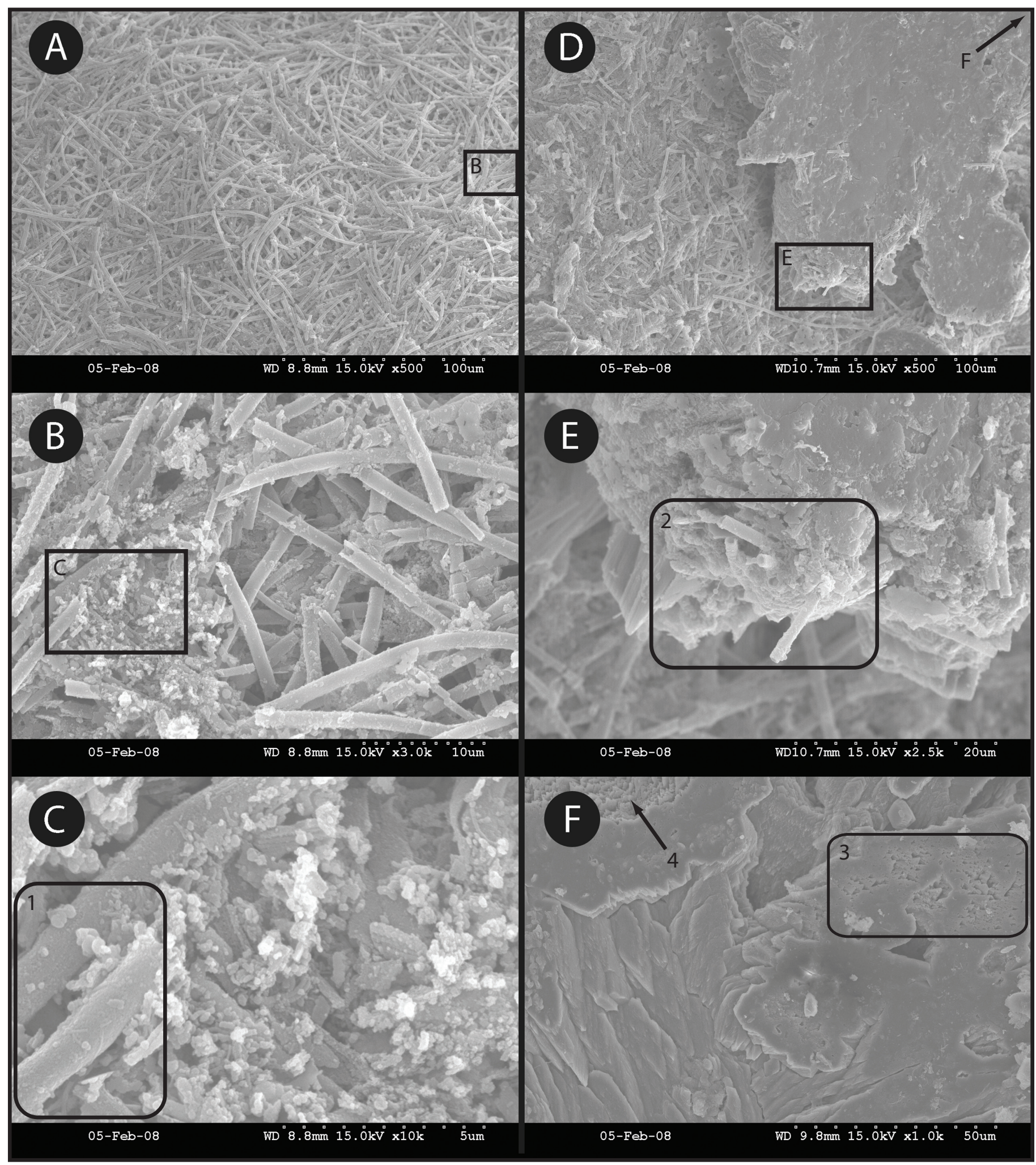

Fig. 4. Example SEM micrographs collected of a 'cornflake' affixed to the cave wall in Thornton's Cave. Rectangles indicate the location of electron micrographs at higher magnification. The collection date, working distance (WD), voltage setting (kV), magnification ( $\mathrm{x}$ ), and scale are included with each electron micrograph. All micrographs collected at high vacuum on a specimen with a Au-Pd sputter coat. A) Lower layer of 'cornflake' comprised of a mat of hollow, 1-mm diameter tubes. B) An enlarged electron micrograph of the mat of tubes that includes a section rich in mineral precipitates trapped on and between the tubes. C) Micrograph at 10k-times magnification within the mat of tubes and mineral precipitates. Visible in the region labeled ' 1 ' are textured tube surfaces at an average scale of less than $0.1 \mathrm{~mm}$. The platy and polygonal nature of the mineral precipitates on and between the tubes is also clearly visible. D) Section of cornflake with a crystalline overgrowth (right) overlying the lower mat of tubes (left). E) Higher magnification of the edge of the crystalline overgrowth. The region labeled ' 2 ' illustrates that the tubes are hollow and are intercalated within the crystal overgrowth. F) The surface of the upper, crystalline layer of the 'cornflake'. The region labeled ' 3 ' and the arrow labeled '4' document triangular pits and sawtooth spikes, respectively, that are consistent with the crystal habit of calcite. 


\section{RESULTS}

Example SEM micrographs presented in Fig. 4 reveal the structure of the 'cornflakes' and the accompanying mineralization. Specifically, the electron micrographs demonstrate a two-layer composition. The basal layer is comprised of a dense mat of sinuous tubes with a near consistent $1-\mu \mathrm{m}$ diameter (Figs. 4A-4C). Platy and polygonal mineral crystals commonly occlude spaces between these tubes (Fig. 4B). At greater magnification, the tubes are visibly textured at a scale of $0.1 \mu \mathrm{m}$ (Fig. 4C). The upper layer comprised of crystals with rhombohedral or scalenohedral crystal habit (Figs. 4D-4F). The tubes are hollow and are found intercalated within some crystals in the upper layer (Fig. 4F).

In the XRD data from the bulk powder of the 'cornflakes' presented in Fig. 5, diffracted X-rays produce a plot of intensity versus the diffraction angle, $2 \theta$, from the Bragg equation. The resulting diffraction spectra, compared against known reference patterns, identified only calcite in the 'cornflake' samples.

In Fig. 6, SEM micrographs of the marble tablets collected prior-to and following the deployment in Thornton's Cave within the acrylic chambers (Fig. 6A) document the effects of the water chemistry and the films collecting on the tablet surfaces (Figs. 6B-6E). In general, the polished surfaces are little altered by dissolution during the five months of deployment in low water levels during the winter dry season, particularly in the filtered sample (Figs. $6 \mathrm{~B} \& 6 \mathrm{C})$. Before and after measurements of mass indicated that only $0.2 \mathrm{~g}$ or $0.25 \%$ of the tablet mass was removed. Before and after measurements of the mass in the unfiltered tablet again show that $0.2 \mathrm{~g}$ or $0.25 \%$ was removed; however, the unfiltered tablet accumulated biomass and mineral precipitation during deployment (Figs. 6C \& 6D), a fact that may obfuscate some of the lost mass.

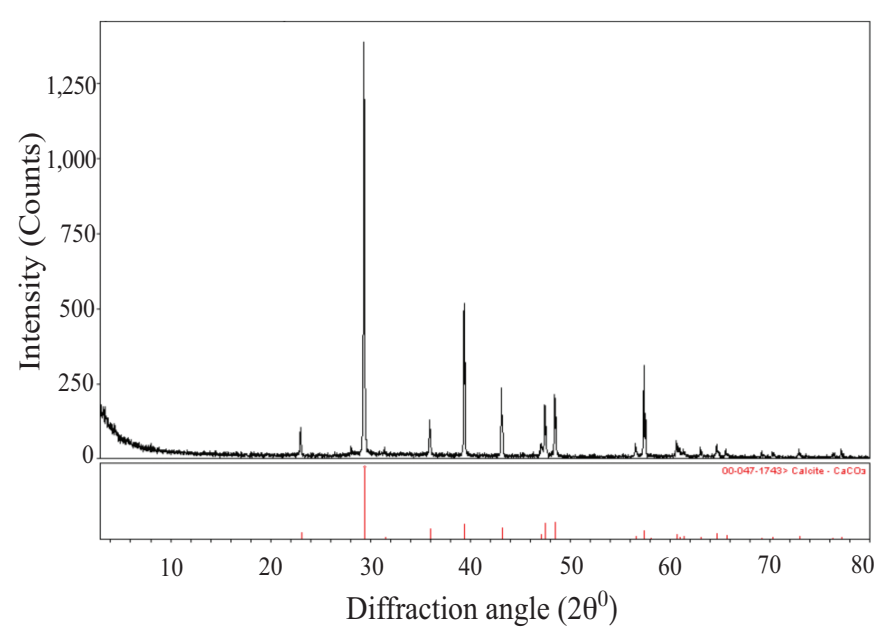

Fig. 5. XRD spectra from a sample of powdered 'cornflake'. The diffraction data closely match the reference standard for the mineral calcite shown in red beneath the spectra.
Closer surface analysis of the unfiltered tablet after deployment illustrates the presence of hollow tubes and mineralization similar in type and morphology to the 'cornflakes' on the cave wall (compare Fig. 4B with Figs. 7A \& 7C). The EDS data of the surface mineralization on the unfiltered tablet (Fig. 7B) are rich in $\mathrm{Ca}$ and $\mathrm{O}$ with lesser amounts of $\mathrm{Fe}$ and $\mathrm{C}$. In contrast, the EDS data from the hollow tubes affixed to the unfiltered tablet (Fig. 7D) are rich in $\mathrm{Fe}$ and $\mathrm{O}$ with lesser amounts of $\mathrm{Ca}$ and $\mathrm{C}$. For comparison, the bulk EDS data from 'cornflakes' (Fig. 8A) and the hollow tubes in the 'cornflakes' (Fig. 8B) mirror the results from the unfiltered tablet. Moreover, and of particular interest, the EDS results form Thornton's Cave are comparable to the data collected by the FGS for the recently discovered 'rusticle' formations in Weeki Wachee Springs (compare Figs. 3B, 7D, \& 8B) (Cindy Fischler, pers. comm., 2010).

The DNA in the orange surface films replicated during PCR with the mofA primer and resulted in a rise above background fluorescence for the $1 \mu \mathrm{L}, 5$ $\mu \mathrm{L}$, and $10 \mu \mathrm{L}$ samples after 27,28 , and 29 cycles, respectively, with no concurrent amplification in the negative controls (Fig. 9A), an indication of the likely presence of the gene in the surface films. The melting point analysis of the amplified PCR product (Fig. 9B) revealed a jump in fluorescence centered at $89^{\circ} \mathrm{C}$ without a similar increase in the negative controls. These results strongly suggest that the amplified PCR product is a distinct DNA fragment.

The data from the agarose electrophoresis experiment establish a base-pair length more than 120 and less than 150 for each of the three sample volumes of the amplified PCR product (Fig. 9C). For comparison, the measured length of the mofA gene of Leptothrix sp. is 127 base pairs. The negative control specimens of Bacteroides 16S rDNA and water show no base-pair bands in the electrophoresis gel (Fig. 9C).

\section{DISCUSSION}

Origin of the 'cornflakes' and fibrous membranes

Orange stains are ubiquitous to the walls and the sediments of Thornton's Cave (Fig. 2A). Likewise, concentrations of insoluble $\mathrm{Fe}$ (III) can be seasonally high, particularly during the low-water conditions of extended periods of dry weather. McGee (2010) addressed the occurrence of Fe in Thornton's Cave and using principle component analysis attributed the primary source to surface soils and runoff, in addition to in-situ oxidation of iron-bearing minerals in the limestone.

Also during the dry season and low water levels, orange-stained films cover the surface of cave pools (Fig. 2B). This surface film has a tendency to fragment into polygonal rafts (Fig. 2C), which accumulate on the cave walls at the mean water table as 'cornflakes'. When water levels rise rapidly, such as the period documented by McGee (2010) at the onset of the summer 2009 wet season and ENSO event, the surface films adhere to the ceiling and remain affixed as water levels lower. As these films dry, they peel from the ceiling, and hang into the passage as the fibrous membranes. 


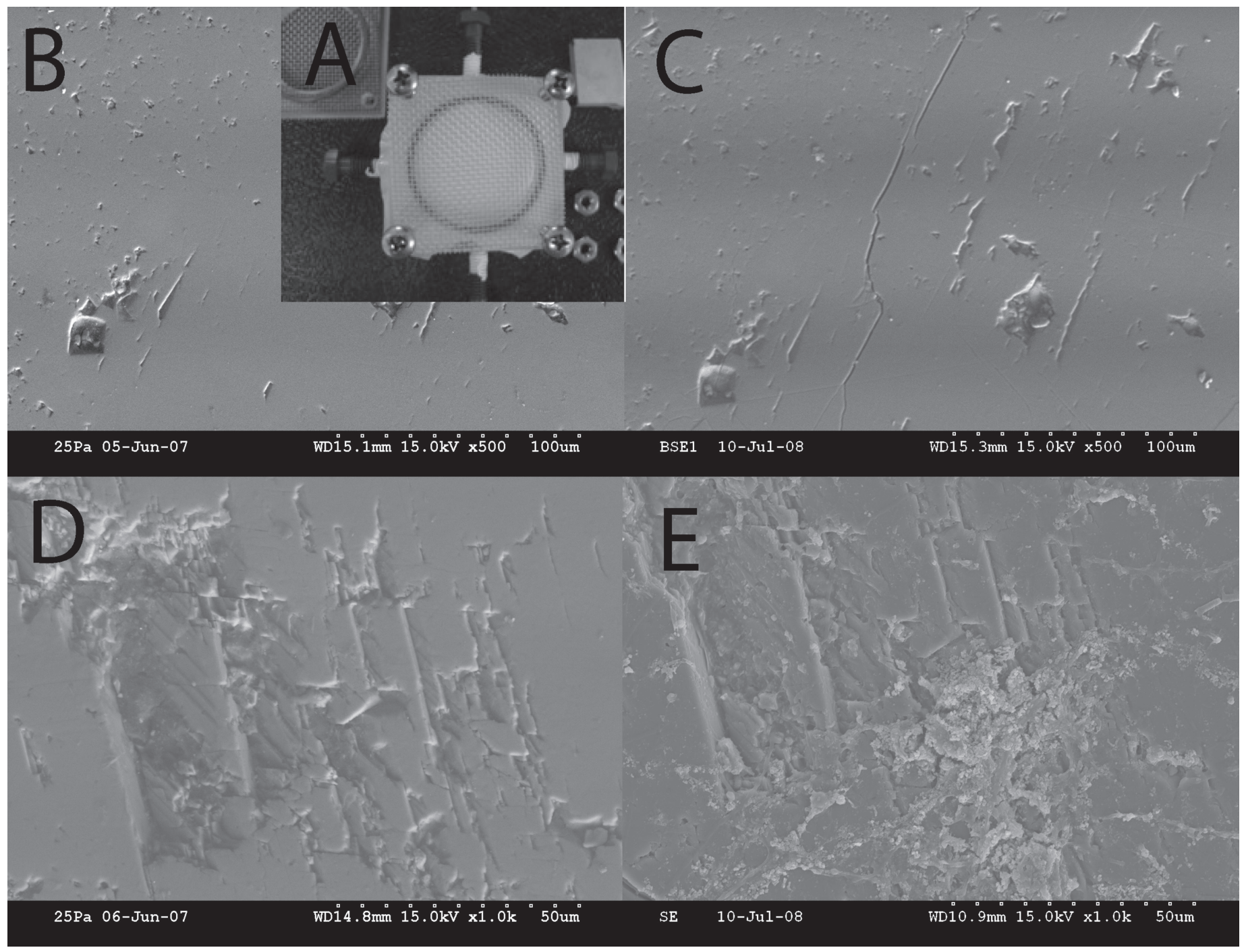

Fig. 6. A) Acrylic chamber with a $0.2 \mathrm{~mm}$ diffusion membrane and O-ring isolating a polished marble tablet from microorganisms in the cave pool. (B-E) SEM micrographs collected of marble tablets prior to and following a five-month deployment at an initial depth of $30 \mathrm{~cm}$ in a cave pool within Thornton's Cave (the 'Near Deep' section of Fig. 1). Au-Pd sputter coats were applied to the tablets after deployment. Vacuum settings, collection date, working distance (WD), voltage setting (kV), magnification (x), and scale are included with each electron micrograph. B) Pre-deployment micrograph of the marble tablet from the acrylic chamber with a diffusion membrane. C) Post-deployment electron micrograph of same site as 'B' indicating little or no change to the tablet surface. D) Pre-deployment electron micrograph of the marble tablet in the acrylic chamber without a diffusion membrane. E) Post-deployment electron micrograph of the same site as ' $D$ ' following a stepped glutaraldehyde, HMDS, and ethanol fixation and dehydration that shows little or no etching or pitting of the tablet surface and the accumulation of biologic material and crystal overgrowth.

We base these interpretations upon direct evidence in the cave as well as morphological and compositional similarity between the surface of the unfiltered marble tablet after deployment in the cave pool and the inactive 'cornflakes' on the cave walls. For example, SEM micrographs of the 'cornflakes' (Figs. 4A-4C) and the unfiltered tablet (Figs. 7A \& 7B) both reveal hollow tubes consistently measuring $1 \mu \mathrm{m}$ in diameter. Both sets of electron micrographs also show platy and polygonal mineralization accumulating along with these tubes (Figs. 4B \& $7 \mathrm{C}$ ). EDS data from both the unfiltered tablet (Figs. 7B \& 7D) and the 'cornflakes' (Fig. 8) have the same elemental characteristics, namely the tubes in both are enriched in $\mathrm{Fe}$ and $\mathrm{O}$ and the mineralization is largely comprised of $\mathrm{Ca}$ and $\mathrm{O}$.

\section{Biological and mineralogical structure of the biofilms and 'cornflakes'}

The combined analyses from the SEM, EDS, and PCR (Figs. 4-9) suggest that the biofilms in Thornton's Cave are composed of a mat of hollow tubes created by the bacteria Leptothrix sp., a common chemoheterotrophic and Fe-oxidizing bacteria in the near-surface realm (Spring, 2006; Ghiorse, 1984). In the SEM imagery (Figs. 4A-4C, 4E, 7A \& 7C) the hollow tubes have a consistent size ( $1 \mu \mathrm{m}$ in diameter) and morphology consistent with the sheaths of Leptothrix sp. (e.g. Fig. 11 of Gilbert et al., 2005). The enriched levels of $\mathrm{Fe}$ and $\mathrm{O}$ documented in the tubes by the EDS data (Figs. 7D \& 8B) imply that oxides of Fe(III), likely ferric oxyhydroxide $(\mathrm{FeOOH})$, is the dominant mineralogy. In the PCR results we demonstrate that 


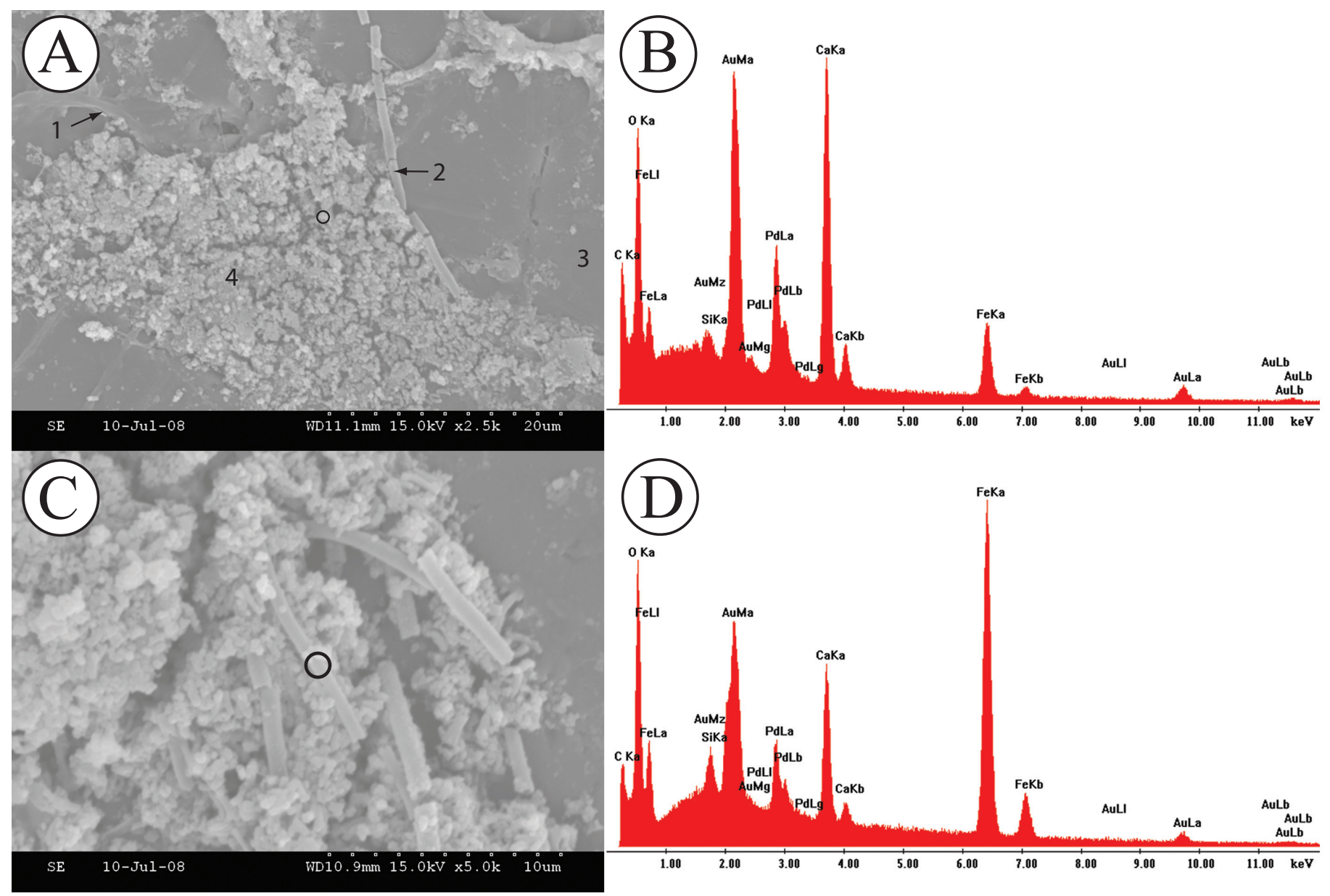

Fig. 7. SEM micrographs and EDS spectra collected from the marble tablet deployed in an unfiltered acrylic chamber for five months in the waters of Thornton's Cave. Vacuum settings, collection date, working distance (WD), voltage setting (kV), magnification (x), and scale are included with each electron micrograph. Biological materials and other mineralization were affixed to the sample using a stepped glutaraldehyde, HMDS, and ethanol fixation and dehydration. Au-Pd sputter coats were applied to these tablets after deployment. A) Electron micrograph from the upper left corner of the tablet. Note the visible connective tissues, such as at '1', hollow tubes at '2', unaltered tablet surface at ' 3 ', and a zone of mineralization at '4'. The open circle represents the site where EDS were collected. B) EDS spectrum taken from center of electron micrograph in 'A' that reveals peaks consistent with the Au and Pd coating. Additional peaks correspond with $\mathrm{Ca}, \mathrm{O}$, and $\mathrm{C}$ (the components of calcite). Lesser amounts of Fe are present. C) Electron micrograph from the lower right corner of the tablet. The open circle represents the site where EDS were collected. D) EDS spectrum taken from center of electron micrograph in 'C' that reveals peaks consistent with the $\mathrm{Au}$ and $\mathrm{Pd}$ coating. Additional peaks correspond with $\mathrm{Fe}$ and $\mathrm{O}$ (the components of ferric oxyhydroxide $\mathrm{FeOOH}$ ). Lesser amounts of $\mathrm{Ca}$ and $\mathrm{C}$ are present.

a primer keyed to the mofA gene of Leptothrix sp. amplifies the DNA extracted from the active biofilm (Fig. 9A). Agarose electrophoresis of the PCR amplified product suggests a base-pair length between 120 and 150 , which spans the 127 base-pair length of the mofA gene of Leptothrix sp. (Fig. 9C). While mofA is a gene related to $\mathrm{Mn}$ oxidation, it is specific to Leptothrix sp., which may oxide both Mn and Fe: "The manganese oxidation genes of Leptothrix [sp.]... are not homologous to the unidentified presumptive manganese oxidation genes from other genera" (Siering \& Ghiorse, 1997).

Leptothrix sp. is known to thrive in waters of near neutral $\mathrm{pH}$, the case in Thornton's Cave where the $\mathrm{pH}$ registers an average value of 6.5 (McGee, 2010). In these waters, the oxidation of soluble $\mathrm{Fe}(\mathrm{II})$ produces insoluble $\mathrm{Fe}(\mathrm{III})$, largely in the form of $\mathrm{FeOOH}$. To prevent hydrolysis and mineralization within the cell, Leptothrix $s p$. oxidizes $\mathrm{Fe}(\mathrm{II})$ in solution by secreting heteropolysaccharides that catalyze the precipitation of FeOOH nanoparticles (Banfield et al., 2000). These nanoparticles then bind to proteins and encrust the bacterial sheath (Frankel \& Bazylinski, 2003). In our SEM micrographs of the hollow tubes at greater magnification, such as in Fig. 4C, these encrusting nanoparticles $0.1 \mu \mathrm{m}$ or less in size are visible as a textured surface and provide evidence that some of the iron stains, 'cornflakes', and fibrous membranes in the cave may be biomineralizations related to ironoxidation by Leptothrix sp.

SEM micrographs show that the 'cornflakes' are more complex than simply a mat of $\mathrm{FeOOH}-$ encrusted hollow tubes (Figs. 4D-4F). Also present is an overlying layer (Fig. 4D) of rhombohedral and scalenohedral crystals (Fig. 4F). The crystal habit and the XRD results (Fig. 5) identify this mineral as calcite. Of particular interest, this overlying layer is intercalated with the tubes (Fig. 4E) suggesting that it was precipitated directly on the biofilm in the water. Direct observations of the active biofilm support this interpretation (Fig. 2C). In the SEM micrographs 
of the tubes in the 'cornflakes' (Figs. 4B \& 4C) and encrustations on the unfiltered marble tablet (Fig. $7 \mathrm{C})$, platy and polygonal crystals accumulate between the tubes. The EDS data from these crystals in both the 'cornflakes' (Fig. 8A) and the unfiltered tablet (Fig. 7B) are rich in $\mathrm{Ca}$ and $\mathrm{O}$, and are likely combined as calcite as evidenced by the XRD results. Therefore, these small crystals are the likely nucleation sites for the larger overgrowth of calcite that comprises the second layer of the biofilm.

\section{Calcite dissolution and precipitation in Thornton's Cave}

The lack of etchings or borings on highly polished marble tablets deployed for five months in either the filtered or unfiltered microbial diffusion chamber (Fig. 7) point to cave waters that favor calcite-saturated conditions during the period of deployment. Neither tablet lost significant mass during deployment, less than 1\%. In fact, SEM micrographs (Fig. 7A) and EDS data (Fig. 7B) suggest that calcite is actively precipitating on the unfiltered tablet during the study.

In contrast to these observations, the native limestone tablet deployed for 16 months by McGee (2010), in nearly the same location as our tablets, experienced loss of mass, as much as 3.5\%, signifying an environment of calcite undersaturation. We resolve this difference by noting that our tablet experiment was limited to a period of low water level during the winter dry season of 2007 and 2008 when total alkalinity and hardness were quite elevated. The experiment by McGee (2010), on the other hand, spanned a longer period of time in 2009 and 2010, encompassed multiple wet and dry seasons, and

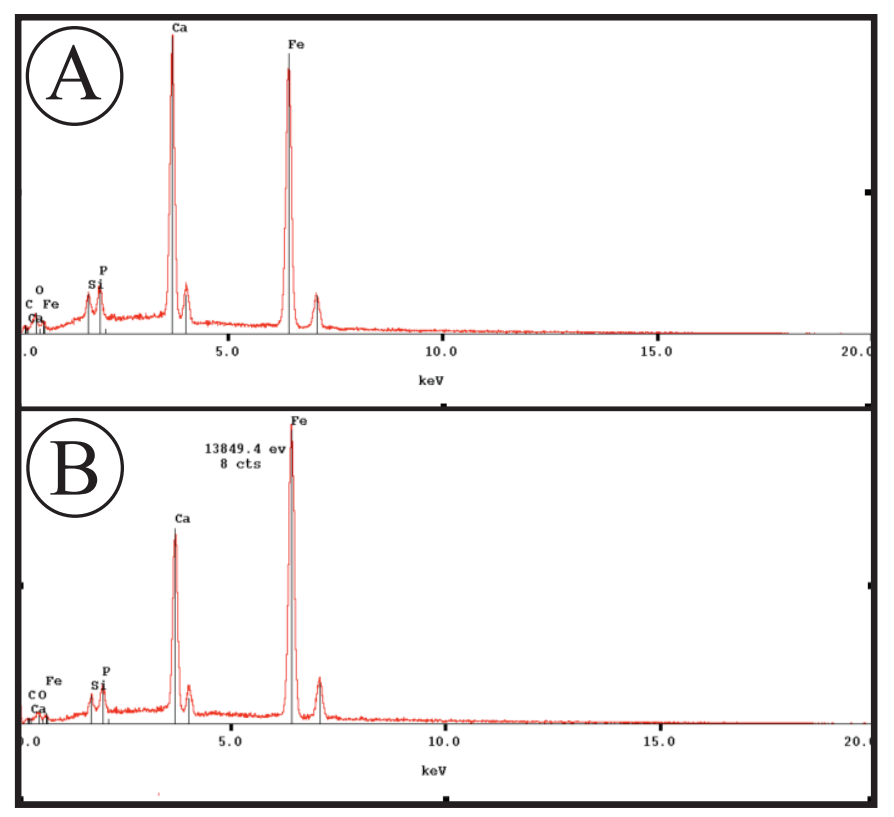

Fig. 8. EDS data collected on the 'cornflakes' taken from the wall in 'The Deep' section of Thornton's Cave (Fig. 1). A) Representative spectra collected on a large sample size that contains strong peaks for both $\mathrm{Ca}$ and $\mathrm{Fe}$. C) Spectrum collected from the vicinity of a hollow tube that illustrates a higher atomic fraction of $\mathrm{Fe}$ over $\mathrm{Ca}$. The EDS that produced the spectra in Fig. 7 is capable of seeing $\mathrm{C}$ and $\mathrm{O}$ while the EDS that produced the spectra in this Fig. is not really able to see these elements. included contributions from and ENSO event. The higher water levels in her study corresponded on average to lower total alkalinity and hardness. Thus, the long-term trend at Thornton's Cave appears to favor calcite dissolution with periods of time, as in this study, where calcite precipitation might occur.

Calcite precipitation in the biofilms and the 'cornflakes' may involve both biotic and abiotic processes. From the perspective of biotic processes, the presence of Leptothrix sp. or other heterotrophic bacteria may help initiate the nucleation of calcite by altering the carbonate-bicarbonate equilibrium through subtle shifts in the $\mathrm{pH}$ close to the cell membrane. The lack of calcite precipitation on the filtered tablet during the deployment (Figs. 6B \& 6C) supports this possibility. These microscopic crystals might attach to electronegative cell membranes (Wright \& Oren, 2005). Such passive precipitation of calcite is well known from cyanobacterial mats (e.g. Chafetz \& Buczynski, 1992). Bacterial precipitation of calcite is also well documented within soils (e.g. Monger et al., 1991). In caves, Baskar et al. (2006) document calcite precipitation in the vicinity of heterotrophic bacterial collected from stalactites in India, and Curry et al. (2009) associate bacteria with the precipitation of calcite within moonmilk deposits in Alaska.

From the perspective of abiotic processes, it is likely that extensive calcite precipitation on the biofilm is related to interactions at the air-water interface. These interactions most importantly involve degassing of dissolved $\mathrm{CO}_{2}$, which using Le Chatelier's principle prompts the reverse reaction in the carbon dioxide-carbonate system, or in representative form

$$
\mathrm{Ca}^{2+}+2 \mathrm{HCO}_{3}^{-} \rightarrow \mathrm{H}_{2} \mathrm{O}+\uparrow \mathrm{CO}_{2}+\downarrow \mathrm{CaCO}_{3} .
$$

This processes is the mechanism by which classical 'calcite rafts' at the surface of pools in caves are formed (e.g. Taylor \& Chafetz, 2004). Data from McGee (2010) that are presented in Table 1 lend important insight. Along the principle path of airflow in the cave, concentrations of dissolved $\mathrm{CO}_{2}$ in the cave waters decrease with a concomitant increase in the $\mathrm{CO}_{2}$ concentration of the cave atmosphere. She interprets the increase in cave-air $\mathrm{CO}_{2}$ to in part reflect the respiration of bats, the decomposition of organic matter such as guano, and the microbial respiration in the rock, water, and soil. However, the trend in the cave-water $\mathrm{pCO}_{2}$ also suggests that degassing might occur. This interaction could explain why the 'cornflakes' and fibrous membranes are largely restricted to the Catfish Entrance and 'The Deep' (Fig. 1). Our conceptual model that summarizes the origin and distribution of the biofilms, 'cornflakes', and fibrous membranes in Thornton's Cave is presented in Fig. 10.

\section{Potential role of Leptothrix sp. for removing trace metals in the UFA}

Of interest, but not investigated in this study, are the implications for the removal of dissolved trace metals from groundwater. $\mathrm{FeOOH}$ is particularly important to remediation because its amorphous or colloidal form presents a large surface area for 

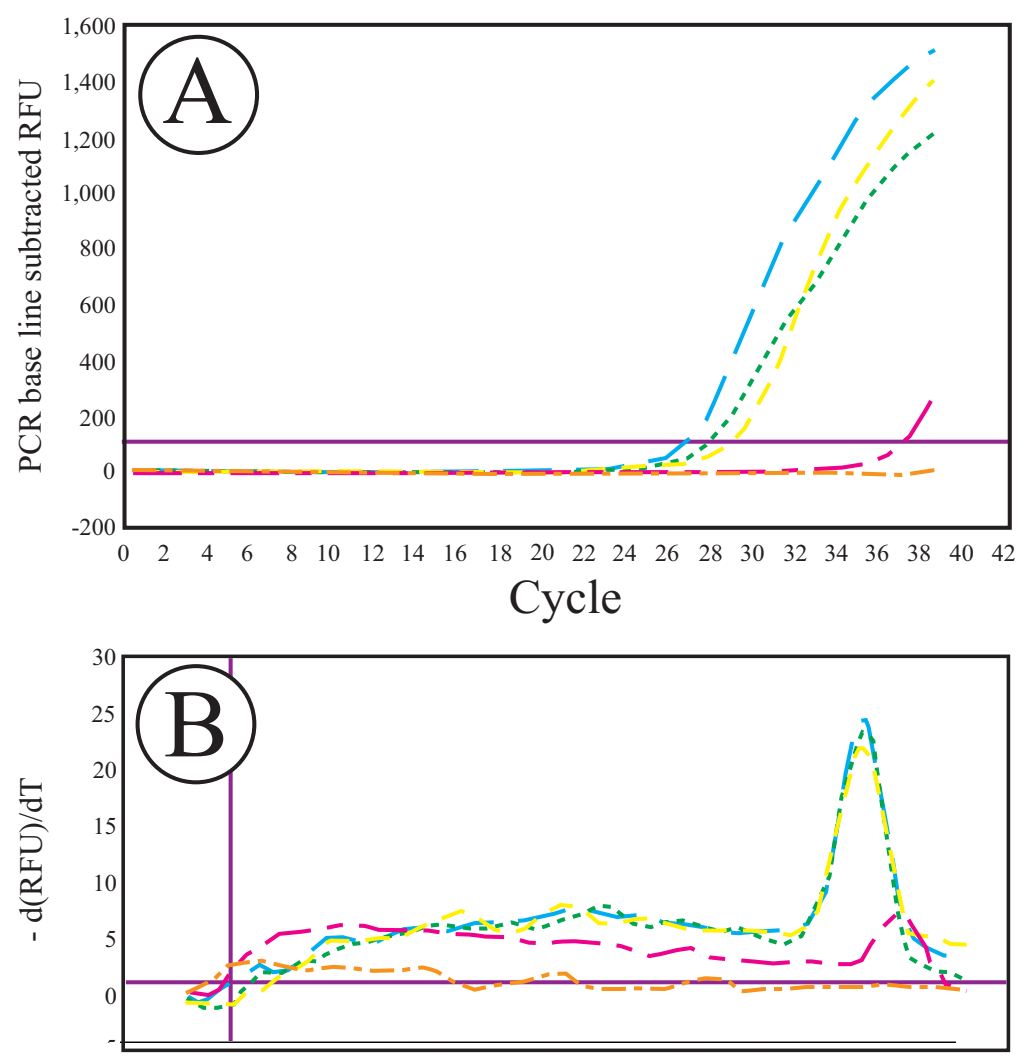

$\begin{array}{lllllllllllllllllllllll}52 & 54 & 56 & 58 & 60 & 62 & 64 & 66 & 68 & 70 & 72 & 74 & 76 & 78 & 80 & 82 & 84 & 86 & 88 & 90 & 92 & 94 & 96\end{array}$

$\mathrm{T}\left({ }^{\circ} \mathrm{C}\right)$

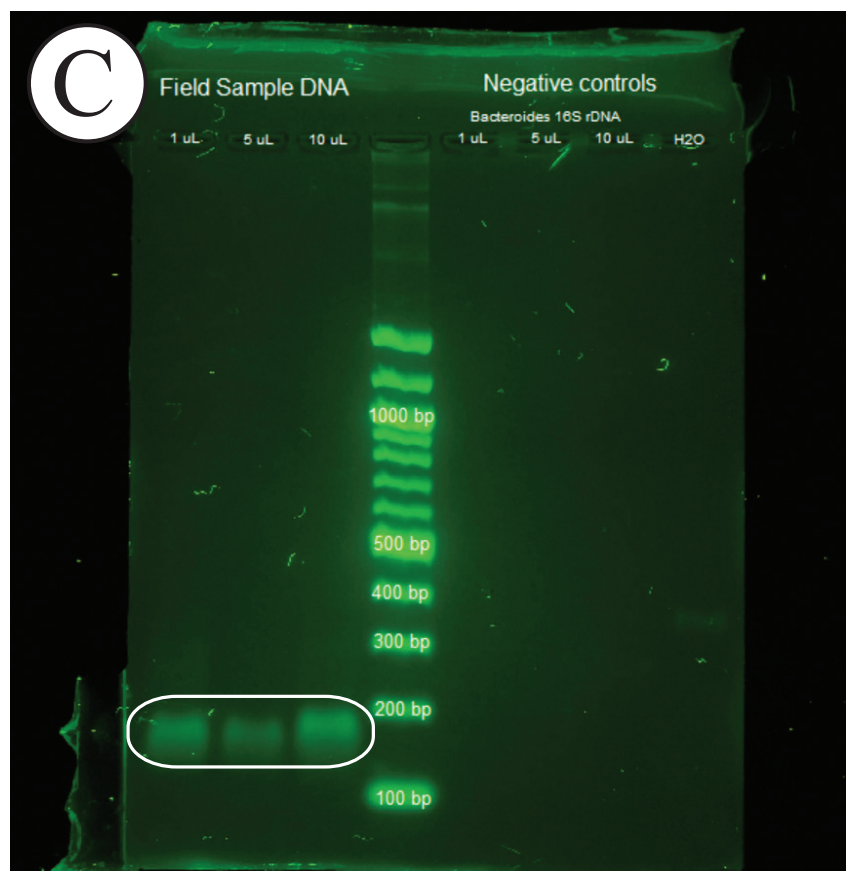

metal absorption (e.g. Sato et al., 2003). For example, in a test on soils contaminated with canal dredgings, coal fly ash deposits, and low-level alkali waste leachate, Hartley et al. (2004) documented a significant drop in arsenic concentrations in all soils amended with $\mathrm{FeOOH}$. Therefore, of specific interest to Florida is the capacity for the $\mathrm{FeOOH}$ produced by Leptothrix $\mathrm{sp}$. to mediate $\mathrm{As}(\mathrm{III})$ and $\mathrm{As}(\mathrm{V})$ mobilized within the UFA during the oxidation of pyrite (Price, 2003). Limiting arsenic mobilization is particularly relevant during the injection of oxygenated waters during the operation of aquifer storage and recovery systems (Arthur et al., 2002).

Based upon the data from this study and in light of the recent underwater discoveries at Weeki Wachee Springs (Fig. 3), it is likely that our investigations at Thornton's Cave represent a microbe-mineral association that is far from unique within Florida caves and karst. Furthermore, it is possible that in-situ colonies of Leptothrix sp. or similar Fe-oxidizing bacteria exist throughout the UFA. The presence of Feoxidizing bacteria could, for example, contribute to the results of Haque \& Johannesson (2006) who used redox geochemistry to model an overall reduction in dissolved As(III), As(V), and $\mathrm{Fe}(\mathrm{II})$ concentrations within down-gradient, progressively reducing wells along a flowpath in the confined portion of the UFA in west-central Florida. While their results correctly interpret the reducing environments in down-gradient wells to promote the formation of pyrite, marcasite, and arsenide, it is alternatively possible that the progressive oxidation in upgradient wells by bacteria such as Leptothrix sp. can create $\mathrm{FeOOH}$ to which As adsorbs. Regardless, these considerations reveal the potential role of Fe-oxidizing bacteria upon the mobility of trace metals in Florida groundwater.

\section{CONCLUSIONS}

Results from this study provide one example of how Fe-oxidizing bacteria contribute to the development of biofilms and interesting mineralizations of ferric oxyhydroxide (FeOOH) and calcite $\left(\mathrm{CaCO}_{3}\right)$ within the karst of the unconfined UFA of west-central Florida. In Thornton's Cave, regular input of water from the

Fig. 9. PCR and agarose electrophoresis of DNA extracted from the orange film on the surface of a cave pool in Thornton's Cave (Fig. 1). A) PCR reaction with a primer specific to the mofA gene of Leptothrix sp. Cyan (long dash), green (short dash), and yellow (medium dash) curves represent mofA reactions with $1 \mu \mathrm{l}, 5 \mu \mathrm{l}$, and $10 \mu \mathrm{l}$ of the biofilm DNA, respectively. Reduced sample volumes take more reaction cycles to rise above threshold fluorescence (solid purple horizontal line). The magenta (long and medium dash) curve is representative of the reaction of the mofA primer with water. The orange (medium and short dash) curve is representative of the lack of reaction between mofA and Bacteroides 16S rDNA. B) Melting point analysis of PRC amplified products. The amplified mofA from the biofilm DNA (cyan (long dash), green (short dash), and yellow (medium dash) curves) have a peak fluorescence at approximately $89^{\circ} \mathrm{C}$. Water, magenta (long and medium dash), and Bacteroides 16S rDNA, orange (medium and short dash), do not experience a similar fluorescence peak above the threshold value (solid purple horizontal line). C) Agarose electrophoresis of the PCR products from $1 \mu \mathrm{l}, 5 \mu \mathrm{l}$, and $10 \mu \mathrm{l}$ of the biofilm DNA (left); $1 \mu \mathrm{l}, 5$ $\mu \mathrm{l}$, and $10 \mu \mathrm{l}$ of Bacteroides $16 \mathrm{~S}$ rDNA (right); and water (far right). Data are compared against a New England Biolabs $1 \mathrm{~Kb}$ ladder (center). Movement in the gel occurred in a two-hour window at an electric-field strength of $7 \mathrm{~V} / \mathrm{cm}$. The PCR products from the surface film DNA for each sample volume show a base-pair length between 120 and 150 (highlighted in white). 
Withlacoochee River during high water levels, soils and vegetative matter from the numerous entrances, and bat guano provide an organic-rich environment in the aphotic zone. Measurements of cave-water and riverwater chemistry document an aqueous environment with near-neutral $\mathrm{pH}$, and iron input from surface runoff and the adjacent river. Chemoheterotrophic bacteria, such as the Fe-oxidizer Leptothrix sp. thrive in this environment and create widespread biofilms in the cave, particularly during low-waterlevel conditions. The associated high total alkalinity and hardness during low water levels, combined with likely $\mathrm{CO}_{2}$ degassing from the cave waters likely contribute to the precipitation of calcite on these biofilms. One result is the 'cornflakes' with two layers:
1) a dense mat of $\mathrm{FeOOH}$-encrusted hollow tubes, and 2) an overlying, and sometimes intercalated, layer of calcite. Recent similar discoveries in other Florida caves indicates that Fe-oxidizing bacterial may be present throughout the UFA and therefore may be an important consideration when investigating the mobility of trace metals in Florida groundwater.

\section{ACKNOWLEDGMENTS}

The authors greatly appreciate the willingness of Ray and Sharon Thornton to allow cavers and scientists on their property during the past several years. Likewise, we are indebted to Robert Brooks and Tom Turner for their years of work with landowners, their participation in cave survey, and their assistance

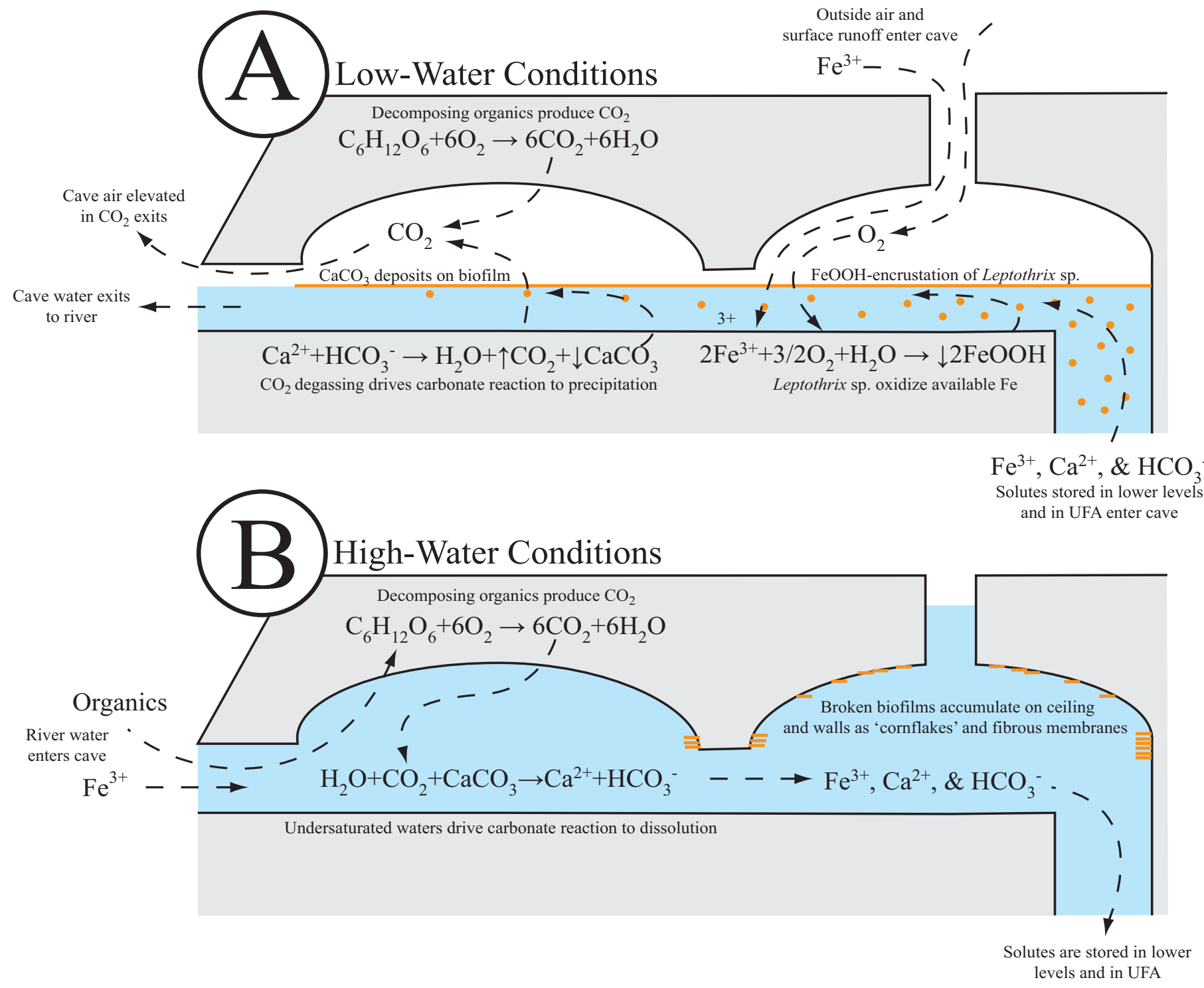

Fig. 10. Conceptual model that outlines the development of biofilms and associated mineralization in Thornton's Cave. A) In low-water conditions during the dry season, airflow through the cave conveys oxygen and soil runoff brings in iron. Oxidation of the iron by bacteria, such as Leptothrix sp., biomineralize $\mathrm{FeOOH}$ as encrusting sheaths and form a biofilm at the water surface. Simultaneous degassing of $\mathrm{CO}_{2}$ from cave waters and the release of $\mathrm{CO}_{2}$ by organic respiration enriches the $\mathrm{pCO}_{2}$ of the cave air. Reduced $\mathrm{pCO}_{2}$ in the water and high levels of and dissolved $\mathrm{Ca}^{2+}$ and $\mathrm{HCO}_{3}{ }^{-}$from the UFA promote calcification of the biofilm. $\mathrm{B}$ ) In high-water conditions during the wet season, river waters, containing dissolved iron, flood the cave and recharge the UFA. Organics in the water and runoff decompose, releasing $\mathrm{CO}_{2}$ into the cave water. Relatively undersaturated conditions promote the dissolution of the limestone bedrock. These higher water levels attach the biofilm to the walls and the ceiling. When water stage drops, these fragments of biofilm remain affixed and dry into the 'cornflakes' and fibrous membranes. 
with site monitoring and sampling. Dorien K. McGee provided insightful discussions, hard work, and years of collaboration on this and other projects. She also graciously permitted data from her dissertation to support a portion of this work. Funding sources have included a USGS Mendenhall to Florea for sampling and SEM analysis, and travel assistance by WKU to Brewer and Noe-Stinson to collect samples and present an earlier version of this work. The USF-CMS, the PSU-MRL, and the WKU Waters Laboratory each provided space and equipment time for this project. Cindy Fischler and Harley Means at the FGS supplied SEM and EDS data for the 'rusticle' formations in Weeki Wachee Springs. Journal editor Jo De Waele, guest editor Bogdan P. Onac, and two anonymous reviewers provided useful commentary and welcome suggestions for improving the quality and content of this manuscript.

\section{REFERENCES}

Arthur J.D., Dabous A.A. \& Cowart J.B., 2002 Mobilization of arsenic and other trace elements during aquifer storage and recovery, southwest Florida. In: Aiken J.R. \& Kuniansky E.L. (Eds.) U.S. Geological Survey Artificial Recharge Workshop Proceedings, April 2-4, 2002, Sacramento, California. U.S. Geological Survey Open File Report 02-89, p. 47-50.

Banfield J.F., Welch S.A., Zhang H., Thomsen-Ebert T. \& Penn R.L., 2000 - Aggregation-based crystal growth and microstructure development in natural iron oxyhydroxide biomineralization products. Science 289: 751-754.

Baskar S., Baskar, R., Mauclaire, L. \& McKenzie, J. A., 2006 - Microbially induced calcite precipitation in culture experiments: Possible origin for stalactites in Sahastradhara caves, Dehradun, India. Current Science 90(1): 58-64.

Baskar S., Baskar R., Lee N., Kaushik A, \& Theophilus P.K., 2008 - Precipitation of iron in microbial mats of the spring waters of Borra Caves, Vishakapatnam, India: some geomicrobiological aspects. Environmental Geology, 56: 237-243. DOI $10.1007 / \mathrm{s} 00254-007-1159-y$

Budd D.A. \& Vacher H.L., 2004 - Matrix permeability of the confined Floridan Aquifer. Hydrogeology Journal, 12(5): 531-549.

Casanova J., Bodénan, F., Négrel, P. \& Azaroual, M., 1999 - Microbial control on the precipitation of modern ferrihydrite and carbonate deposits from the Cézallier hydrothermal springs (Massif Central, France). Sedimentary Geology 126(1-4): 125-145. DOI:10.1016/S0037-0738(99)000366

Chafetz H.S. \& Buczynski C., 1992 - Bacterially induced lithification of microbial mats. Palaios, 7: 277-293.

Curry M.D., Boston, P.J., Spilde, M.N., Baichtal, J.F., Campbell, A.R., 2009 - Cottonballs, a unique subaqeous moonmilk, and abundant subaerial moonmilk in Cataract Cave, Tongass National Forest, Alaska. International Journal of Speleology 38(2): 111-128.
Cullimore R.D., Pellegrino C. \& Johnston L., 2002 RMS Titanic and the emergence of new concepts on consortial nature of microbial events. Review of Environmental Contaminants and Toxicology, 173: $117-141$.

Davis D.G., Palmer M.V. \& Palmer A.N., 1990 - Extraordinary subaqueous speleothems in Lechuguilla Cave, New Mexico. NSS Bulletin, 52: 7086.

Emerson D. \& Moyer, C.L. 2002 - Neutrophilic FeOxidizing Bacteria Are Abundant at the Loihi Seamount Hydrothermal Vents and Play a Major Role in Fe Oxide Deposition. Applied and Environmental Microbiology 68(6): 3085-3093. DOI: 10.1128/AEM.68.6.3085-3093.2002

Emerson D. \& Revsbech, N.P., 1994 - Investigation of an Iron-Oxidizing Microbial Mat Community Located near Aarhus, Denmark: Field Studies. Applied and Environmental Microbiology 60(11): 4022-4031.

Fischler C., 2010 - Personal communication via email on December $8^{\text {th }}$.

Florea L.J., 2006 - Architecture of air-filled caves within the karst of the Brooksville Ridge, WestCentral Florida. Journal of Cave and Karst Studies, 68(2): 64-75.

Florea L.J. \& Vacher H.L., 2006 - Springflow hydrographs: Eogenetic vs. telogenetic karst. Ground Water, 44(3): 352-361. DOI: 10.1111/j.17456584.2005.00158.x

Florea L.J. \& Vacher H.L., 2007 - Eogenetic karst hydrology: Insights from the 2004 hurricanes, Peninsular Florida. Ground Water, 45(4): 439-446. DOI: $10.1111 / \mathrm{j} .1745-6584.2007 .00309 . x$

Florea L.J., Vacher H.L., Donahue B. \& Naar D., 2007 - Quaternary cave levels in peninsular Florida. Quaternary Science Reviews, 26: 1344-1361.

Frankel R.B. \& Bazylinski D.A., 2003 - Biologically Induced Mineralization by Bacteria. Reviews in Mineralogy and Geochemistry, 54(1): 95-114. DOI: $10.2113 / 0540095$

Fratesi S.E., Lynch F.L., Kirkland B.L. \& Brown L.R., 2004 - Effects of SEM preparation techniques on the appearance of bacteria and biofilms in the Carter Sandstone. Journal of Sedimentary Research, 74(6): 858-867.

Frierdich A.J. \& Catalano J.G., 2009 - Nanocrystalline Iron and Manganese Oxide Deposits in Pautler Cave: Implications for Heavy Metal Transport and Sequestration in a Shallow Karst Aquifer. Geological Society of America Abstracts with Programs, 41(7): PAGES??

Gheriany I.A., Bocioaga D., Hay A.G., Ghiorse W.C., Shuler M.L. \& Lion L.W., 2009 - Iron Requirement for Mn(II) Oxidation by Leptothrix discophora SS-1. Applied and Environmental Microbiology, 75(5): 1229-1235. DOI: 10.1128/AEM.02291-08

Ghiorse W.C., 1984 - Biology of Iron- and Manganese-Depositing Bacteria. Annual Reviews in Microbiology, 38: 515-550.

Gilbert P.U.P.A., Abrecht, M., \& Frazer, B.H., 2005 - The Organic-Mineral Interface in Biominerals. Reviews in Mineralogy \& Geochemistry, 59: 157185. DOI: $10.2138 / \mathrm{rmg} .2005 .59 .7$ 
Hartley W., Edwards, R. \& Lepp, N.W., 2004 - Arsenic and heavy metal mobility in iron oxide-amended contaminated soils as evaluated by short- and long-term leaching tests. Environmental Pollution 131(3): 495-504.

Haque S.E. \& Johannesson K.H., 2006 - Concentrations and speciation of arsenic along a groundwater flow-path in the Upper Floridan aquifer, Florida, USA. Environmental Geology 50: 219-228. DOI 10.1007/s00254-006-0202-8

Karst Underwater Research, 2009 - Weeki Wachee Spring, Hernando County, Florida Continuing Exploration 2009 Report, 31.p

Katsoyiannis I.A. \& Zouboulis A.I., 2004 - Application of biological processes for the removal of arsenic from groundwaters. Water Research, 38(1): 1726. DIO 10.1016/j.watres.2003.09.011

Konhauser K.O., 1997 - Bacterial iron mineralization in nature. FEMS Microbiology Review, 20: 315326.

Konhauser K.O., 1998 - Diversity of bacterial iron mineralization. Earth Science Reviews, 43: 91-121.

Li D., Li Z., Yu J., Cao N., Liu R. \& Yang M., 2010 Characterization of Bacterial Community Structure in a Drinking Water Distribution System during an Occurrence of Red Water. Applied and Environmental Microbiology 76(21): 7171-7180. DOI:10.1128/AEM.00832-10

Lowenstam H.A. \& Weiner S., 1989. On Biomineralization. New York: Oxford University Press, 324 p.

Martin J. M., Screaton E.J. \& Martin J.B., 2006 Monitoring well responses to karst conduit head fluctuations: Implications for fluid exchange and matrix transmissivity in the Floridan aquifer. In: Harmon R. \& Wicks C.W. (Eds.) - Perspectives on Karst Geomorphology, Hydrology, and Geochemistry - A Tribute Volume to Derek C. Ford and William $B$. White. Boulder, Colorado: Geological Society of America, 209-217.

Martin J.B. \& Dean R.W., 2001 - Exchange of water between conduits and matrix in the Floridan aquifer. Chemical Geology, 179(1-4): 145-165.

McGee D.K., 2010 - Microbial Influences on Karst Dissolution: The Geochemical Perspective, with a Chapter on Assessment of the Spreadsheets Across the Curriculum Project. PhD Dissertation, University of South Florida, $325 \mathrm{p}$.

Monger H.C., Daugherty L.A., Lindemann W.C. \& Liddell C.M., 1991 - Microbial precipitation of pedogenic calcite. Geology, 19:997-1000

Moore G.W., 1981 - Manganese deposition in limestone caves. In: Beck B.F. (Ed.) - Proceedings of the Eighth International Congress of Speleology. Georgia Southwestern College: 642-645.

Moore P.J., Martin, J.B. \& Screaton, E.J., 2009 Geochemical and statistical evidence of recharge, mixing, and controls on spring discharge in an eogenetic karst aquifer. Journal of Hydrology, 376: 443-455. DOI 10.1016/j.jhydrol.2009.07.052
Northup D.E., Barns, S.M., Yu, L.E., Spilde, M.N., Schelble, R.T., Dano, K.E. et al., 2003 - Diverse microbial communities inhabiting ferromanganese deposits in Lechuguilla and Spider Caves. Environmental Microbiology 5: 1071-1086.

Northup D.E. \& Lavoie K.H., 2001 - Geomicrobiology of Caves: A Review. Geomicrobiology Journal, 18: 199-222.

Peck S.B.. 1986 - Bacterial deposition of iron and manganese oxides in North American caves. NSS Bulletin, 48: 26-30.

Perry R.S., Engel, M.H., Botta, O. \& Staley, J.T., 2003 - Amino Acid Analyses of Desert Varnish from the Sonoran and Mojave Deserts. Geomicrobiology Journal 20: 427-438. DOI: $10.1080 / 01490450390236644$

Price R.E., 2003 - Abundance and mineralogical associations of naturally occurring arsenic in the upper Floridan aquifer, Suwannee Limestone. MS Thesis, University of South Florida, 74 p.

Provencio, P. \& Polyak V.J., 2001 - Iron oxide-rich filaments: Possible fossil bacteria in Lechuguilla Cave, New Mexico. Geomicrobiology Journal, 18: 297-310.

Sato K., Kusuyama, T. \& Tnimura, K. 2003 - Adsorption of heavy metal ions on the surface of metal-incorporated hydrous ferric oxide particles. Materials Science Forum 439: 210-214.

Siering P.L. \& Ghiorse, W.C., 1997 - PCR detection of a putative manganese oxidation gene (mofA) in environmental samples and assessment of mofA gene homology among diverse manganese-oxidizing bacteria. Geomicrobiology Journal 14(2): 109 - 125. DOI: 10.1080/01490459709378038

Spring S., 2006 - The Genera Leptothrix and Sphaerotilus. Prokaryotes, 5: 758-777. DOI: 10.1007/0387-30745-1_35

Taylor P.M. \& Chafetz H.S., 2004 - Floating Rafts of Calcite Crystals in Cave Pools, Central Texas, USA: Crystal Habit vs. Saturation State. Journal of Sedimentary Research, 74 (3): 328-341.

Turner T., 2007 - Personal communication via e-mail. Underwater Society of America, 1975 - International Divers' Guide.

Vacher H.L. \& Mylroie J.L., 2002 - Eogenetic karst from the perspective of an equivalent porous medium. Carbonates and Evaporites, 17(2): 182-196.

White W.A., 1970 - The Geomorphology of the Floridan Peninsula. Florida Bureau of Geology Bulletin 51. Tallahassee.

Wright D.T. \& Oren A., 2005 - Nonphotosynthetic Bacteria and the Formation of Carbonates and Evaporites Through Time. Geomicrobiology Journal, 22:27-53. DOI: 10.1080/01490450590922532

Zhou J.P, Gu Y.Q., Zou C.S. \& Mo M.H. 2007 - Phylogenetic Diversity of Bacteria in an Earth-Cave in Guizhou Province, Southwest of China. The Journal of Microbiology, 45(2): 105-112. 